\title{
Poor accuracy of anti-citrulline antibody test in diagnosis of rheumatoid arthritis in Iran
}

\author{
Varun Dhir · Palvi Goyal
}

Received: 20 September 2012/ Accepted: 24 March 2013/Published online: 4 April 2013

(C) Springer-Verlag Berlin Heidelberg 2013

Sir,

We read with interest the article on the utility of anti-CCP in Iran [1]. Although the authors have mentioned that "anti-CCP was measured by a second-generation ELISA," the authors fail to provide the kit name or the cutoff value recommended by the kit. The study has defined "more than $15 \mathrm{U} / \mathrm{ml}$ as high titer," which suggests they used the Euroimmun anti-CCP ELISA kit (Euroimmun AG, Luebeck, Germany) [2] which recommends a cutoff of $5 \mathrm{RU} / \mathrm{ml}$. However, they mention the ELiA CCP test in the introduction, which recommends a cutoff of $10 \mathrm{U} / \mathrm{ml}$ [3]. It will be interesting to know the accuracy (sensitivity and specificity) when using kit-recommended cutoff apart from "high titer" cutoff used in this study.

The authors found a sensitivity of anti-CCP to be $81 \%$, but found a specificity of only $77 \%$. This low specificity is of concern, being much lower than previously reported and claimed by manufacturers [2-5]. The authors have included 16 patients of "seronegative arthritis" (not defined in the text) out of 100 controls, making one wonder whether some of these were actually rheumatoid arthritis being picked up by the anti-CCP test. Interestingly, this study found rheumatoid factor to have a higher specificity $(85 \%)$ than antiCCP $(77 \%)$ !

Finally, the authors have found 20 RU may be a more appropriate cutoff in their population. This is similar to other studies finding higher cutoffs than those recommended by manufacturers [6] and highlights the need to define population standards, rather than applying kit standards (based on different populations) indiscriminately.

\section{References}

1. Abolghasemi S, Gitipour A, Morteza A (2012) The sensitivity, specificity and accuracy of anti-citrulline antibody test in diagnosis of rheumatoid arthritis. Rheumatol Int [Epub ahead of print]

2. EA_1505_D_UK_A05.pdf Data sheet "Anti-CCP ELISA" http://euroimmune.com/index.php?id=1012\&L=3. Accessed 01 Sept 2012

3. EliA CCP Folder-Phadia http://www.phadia.com/en/Media/Docu ment-Library/Product-Folder-AI/Product-Folder-CCP/. Accessed 01 Sept 2012

4. Nishimura K, Sugiyama D, Kogata Y et al (2007) Meta-analysis: diagnostic accuracy of anti-cyclic citrullinated peptide antibody and rheumatoid factor for rheumatoid arthritis. Ann Intern Med 146(11):797-808

5. Gao F, Ren L, Zhang CQ, Mu FY, You YQ, Liu YH (2011) Diagnostic value of anti-cyclic citrullinated peptide antibody for rheumatoid arthritis in a Chinese population: a meta-analysis. Rheumatol Int [Epub ahead of print]

6. Fabien N, Olsson NO, Goetz J et al (2008) Prevalence of autoantibodies to cyclic citrullinated peptide in patients with rheumatic diseases other than rheumatoid arthritis: a French multicenter study. Clin Rev Allergy Immunol 34:40-44

\footnotetext{
V. Dhir $(\varangle) \cdot$ P. Goyal

Post Graduate Institute of Medical Education and Research,

Chandigarh 160012, India

e-mail: varundhir@gmail.com
} 